\title{
EXAMINING THE MEDIATING EFFECT OF STRATEGIC AGILITY IN THE RELATIONSHIP BETWEEN INTELLECTUAL CAPITAL AND ORGANIZATIONAL EXCELLENCE IN JORDAN SERVICE
}

\author{
ZEYAD FAISAL AL-AZZAM \\ HANI JAZZA'A IRTAIMEH \\ Management Department \\ The World Islamic Science and Education University, Jordan
}

\author{
AMINEH ABDUL HALIM KHADDAM \\ Mis Department \\ Amman Arab University, Jordan
}

\begin{abstract}
This study aims to investigate the effect of intellectual capital and strategic agility on organizational excellence in the service sector of Jordan. A total of 550 questionnaires were collected from respondents who were chosen from the stratified random sampling. The results reveal that intellectual capital and its dimensions, human capital, structural capital and relational capital, have significant impacts on strategic agility as well as organizational excellence. Moreover, the results reveal that strategic agility fully mediates the relationship between intellectual capital and organizational excellence. The findings of this study can have significant implications for the service sector of Jordan.
\end{abstract}

Keywords: Strategic agility, intellectual capital, HRM, excellent performance.

Received: 28/11/2017

Revised: 12/02/2018

Accepted: 28/2/2018

\section{Introduction}

In the knowledge-based economy, business organizations have realized the importance of intangible assets, e.g. intellectual capital, which have been used effectively to accomplish organizational excellence by 
increasing its operations' effectiveness as well as performance. On the other hand, achieving high levels of organizational excellence requires workers with high skills, knowledge, capabilities, competencies and attitudes (Sharabati, Jawad, \& Bontis, 2010). Therefore, organizations started implementing new approaches and techniques to better utilize the physical financial and knowledge assets, and competencies of their human capital (Bontis, 1999).

Many scholars and practitioners investigated the importance of intellectual capital as the source of value creation and competitive advantage. With the rapid development of information technology, the velocity of environmental changes and increasing globalization impacts, a high necessity of controlling and nurturing businesses' intellectual assets is mandatory. It is hypothesised that organizational capability to innovate is closely tied to its intellectual capitals and utilizing its knowledge resource (Bontis, 2011).

Strategically, organizations must adequately evaluate their internal resources to identify their strengths while empowering their weaknesses to strive in opportunities and absorbing threats. Accordingly, the more intellectual capital accumulation, the more innovation initiatives will be produced (Wu, Lin, \& Hsu, 2007; Ling, 2011). Generally speaking, information technology has strongly affected the overall businesses in terms of costs, time, productivity and their performance. The Internet is the vital source of enhancing and sharing knowledge and information. Furthermore, $21^{\text {st }}$ century brings new challenges to organizations to visualize intellectual capital efficiency, as the source of competitive advantage, as well as manage creative and talented workers for organizational strategic decisions, performance, rapid growth, orientation and choices.

In today's ongoing changing, global and hypercompetitive business environment, organizations that operate under uncertainty, chaotic, dynamic and hostility factors are neither safe nor secure but they must be strategically equipped with acumen and agility instead of banking on traditional management techniques and methods in such unpredictable and irregular customers' demands and environmental changes in order to encounter any strategic surprises or challenges that might affect their operations and performance (Abu-Radi, 2013; Doz \& Kosonen, 2010; Curado, Henriques, \& Bontis, 2011; Kazmi \& Naaranoja, 2015). Therefore, the significance of this study demonstrated the effect of strategic agility as a core capability for organizations to take over the opportunities in the marketplace (service sector of Jordan) and get full insights into the dimensions 
of Strategic Agility (SA), Intellectual Capital (IC), and Organizational Excellence (OE). Moreover, this study focused on examining the relationship between strategic agility, intellectual capital and organizational excellence. Then it investigated the effect of strategic agility as a of mediator of both intellectual capital and organizational excellence in the service sector of Jordan.

\section{Research Model and Hypothesis}

The following diagram depicts the research conceptual model and it proposes the relationship between the variables. In the current study, the researchers attempt to examine the relationship between intellectual capital, organizational excellence and agility. Finally in achieving the final research model, a structural equation model was used to investigate the effect of strategic agility as a mediator in the relationship between intellectual capital and organizational excellence (Sekaran \& Bougi, 2016).

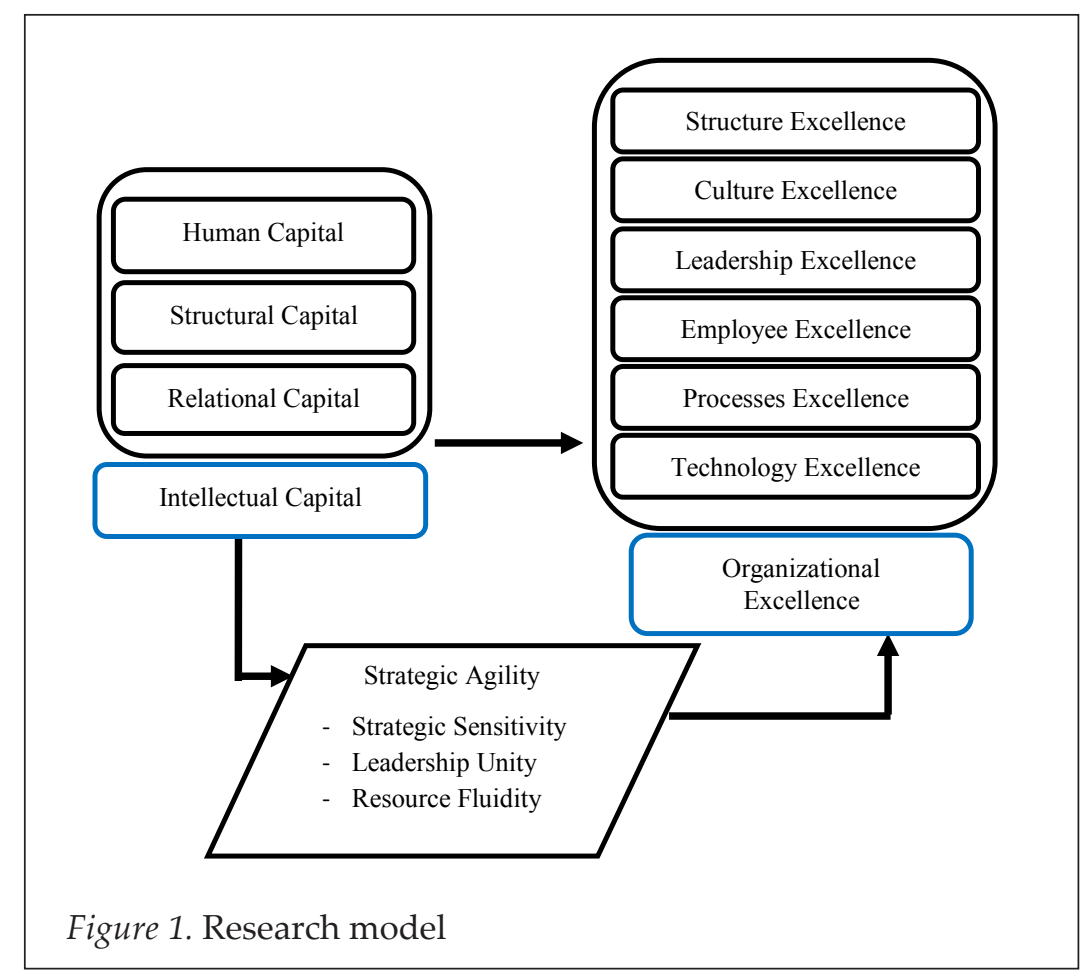

Based on the above model, the researchers developed the following hypothesis: 
$\mathrm{H}_{0} 1$ : There is a significant statistical effect of Intellectual Capital on Organizational Excellence in the Jordan Service Sector.

$\mathrm{H}_{0}$ 2: There is a significant statistical effect of Intellectual Capital on Strategic Agility in the Jordan Service Sector.

$\mathrm{H}_{0} 3$ : There is a significant statistical effect of Strategic Agility on Organizational Excellence in the Jordan Service Sector.

$\mathrm{H}_{0} 4$ : Strategic Agility is mediating the effect in the relationship between IC and OE in the Jordan Service Sector.

\section{Literature Review Intellectual Capital (IC)}

There is a consensus among scholars and researchers that the $21^{\text {st }}$ century will be the age of discontinuity which means that past experiences and traditional management solutions will not be suitable for current and future organizational issues in a severe chaotic world (Mohammad, Ansari, Ologbo, \& Rezaei, 2013). Therefore, organizations, represented by its top management, should be alert, smart and agile enough to address these environmental uncertainties, complexity, hypercompetitive markets and velocity of technological progress (Irtaimeh, Al-Azzam, \& Al-Quraan, 2016). Consequently, to maintain their competitive ability, organizations must evaluate and reactivate their creative, innovative, and intellectual capitals. These can easily generate internal knowledge and at the same time gain external knowledge which, of course, will enhance learning and innovation inside organizations (Hsu \& Fang, 2009).

Several studies had investigated Intellectual Capital and they concluded that IC is the sum of all types of knowledge organizations utilized for competitive advantage and they offer new opportunities, higher performance, and can create value (Stewart, 1997; Youndt, Subramaniam, \& Snell, 2004; Subramanian \& Youndt, 2005). Thus, new challenges forced business organizations to give more attention to their strategic weapons by increasing their skills and abilities which are required nowadays. Moreover, many previous studies have identified three aspects of IC (Youndt et al., 2004; Bhatti \& Zaheer, 2014; Irtaimeh et al., 2016):

1. Human Capital can be defined as the knowledge, skills, expertise, creative and innovative capabilities, competencies 
and abilities residing within individuals' minds (Tacit Knowledge).

2. Structural Capital is the knowledge that is institutionalized and codified within an organization and utilized through databases, manuals, structures, culture, systems, processes and its intellectual assets. It is considered as the infrastructure for Human Capital and can be visualized in terms of learning and sharing knowledge in daily practices.

3. Relational Capital refers to the knowledge embodied within and utilized by interactions between individuals within an organization and with other stakeholders outside the organization.

\section{Strategic Agility (SA)}

Despite placing more emphasis on organizations' processes and operational excellence a long time ago, most of those organizations have been confronted with high speeds of changes and challenges in the marketplace (McCann, Selsky, \& Lee, 2009; Dehaghi \& Navabakhsh, 2014). Thus, one of the core-sustained high performance (achieve overall organizational excellence) depends on the market focus by exploiting opportunities, distinctive capabilities by creating a differentiation, and outlining the competition by improving high performance; of course, to survive and thrive in a dynamic environment is agility (Ismail, Poolton, \& Sharifi, 2011; Irtaimeh, 2017). Therefore, strategic agility involves tactfully sightseeing and acting responsively with ease, high speed and dexterity to environmental changes and challenges. In other words, organizational agility means the ability to cope with undesirable challenges to overcome new and unexpected strategic surprises of the business environment, take over opportunities, create values and satisfy highly demanding customers (Tallon \& Pinsonneault, 2011; Qin \& Nembhard, 2010; Ghafuri, Farhadi, \& Mansouri, 2014; Arbussa, Bikfalvi, \& Marquès, 2017).

Generally, strategic agility is the most powerful technique for strategic orientation and drives the most suitable of strategic alternatives. The ability to be agile is directly related to human performance and the processes and technologies of the organization. Based on the dynamism of competitive environment, Doz and Kosonen (2008, 2010, \& 2014) proposed that strategic agility is mostly required when the market's and the organizations' growth are identical over time. Moreover, they identified three types of strategic agility dimensions, namely strategic sensitivity which means being open 
to as much information, intelligence and innovations as possible by creating and maintaining relationships with a variety of different people and organizations; leadership unity or collective commitment refers to all teams that feel committed. obliged and responsible for the decision taken, and resource fluidity is the ability to easily move resources from a place to another when needed, while Mavengere (2014) restructured these dimension to include strategic sensitivity which means the ability to discover, create, analyze and disseminate knowledge to seize the environmental opportunities and threats. Strategic response is the ability of an organization to configure or reconfigure its resources to quickly react or proact to demands, and collective capabilities which refer to the ability to take advantage of the synthesis of the organizations' resources.

\section{Organizational Excellence (OE)}

As one of the modern management concepts that is widely used nowadays in concurrence with the need of organizations to use different techniques to strive in their strategic goals and build sustainable competitive advantages. To do so, organization excellence is implemented to gain the highest return on investments and value creation. Organizational excellence is clearly defined as the state of superiority in every organizational aspect in everyday activities to exceed customers' expectations (Qawasme, Darqal, \& Qawasmeh, 2013; Al-Qeed, Al-Raggad, Al-Shura, AlQaisieh, \& Al-Azzam, 2016). Moreover, OE can be achieved through $4 \mathrm{P}^{\prime}$ s, namely excellent people, excellent partnerships, excellent processes, excellent technologies, and excellent products (Dahlgaard \& Dahlgard, 1999).

Yet, a strong vision and mission, policies and strategies, values and ethics, workers' development, empowerment and innovation, new suitable technologies, customer relationships, relations with all stakeholders, creative well-being of workers, fully responsible to the public and commitment to the philosophy of excellence are the main critical success factors of OE (Hui \& Chuan, 2002; Sasmita \& Nayantara, 2003). Other scholars have postulated that being aware of the market situation, market share, customers' preferences, reputation, new technologies used in the market used, profitability, volume of sales, financial capital, culture and core competencies needed and used would enhance the opportunities to achieve OE (McNamara, 1997; Foster, 2002; Al-Saudi, 2008). 


\section{Research Methodology}

The current study adopted the demonstrative analytical approach, aiming to examine the mediating effect of strategic agility in the relationship between intellectual capital and organizational excellence in the Jordanian service sector. Jordan is economy is dominated by the services sector as it contributes to $67 \%$ Jordan's GDP compared to other sectors which contribute $33 \%$. Therefore, the target population of this study was managers who work in different service sectors in Jordan including the medical services, higher education, tourism, transport, banking, insurance and computer programming, all of which are distinguished activities able to compete in the world market. Moreover, the measurement of constructs in the study used a five-point Likert scale ranging from 1 "strongly disagree" to 5 "strongly agree". Because an online survey achieves faster results and has provide to be effective in running time, 600 questionnaires were successfully distributed and collected online on a random stratified sample of managers for data analysis. Table 1 shows the demographic variables.

Table 1

Demographic Variables

\begin{tabular}{|c|c|c|c|c|}
\hline No. & Variables & Categories & Frequency & Percent \\
\hline \multirow{2}{*}{1} & \multirow{2}{*}{ Gender } & Male & 370 & 67.3 \\
\hline & & Female & 180 & 32.7 \\
\hline \multirow{4}{*}{2} & \multirow{4}{*}{ Age } & 30 years or less & 131 & 23.8 \\
\hline & & 31 - 39 years & 177 & 32.2 \\
\hline & & $40-45$ years & 156 & 28.4 \\
\hline & & 46 years and above & 86 & 15.6 \\
\hline \multirow[t]{4}{*}{3} & \multirow{4}{*}{$\begin{array}{l}\text { Work } \\
\text { experience }\end{array}$} & Less than 5 years & 47 & 8.6 \\
\hline & & $5-9$ years & 234 & 42.6 \\
\hline & & $10-15$ years & 191 & 34.7 \\
\hline & & 16 years and above & 78 & 14.2 \\
\hline \multirow[t]{2}{*}{4} & Education level & Bachelor and below & 397 & 72.2 \\
\hline & & Graduate & 153 & 27.8 \\
\hline
\end{tabular}




\section{Data Analysis and Results}

The Statistical Package for Social Sciences (SPSS version 20) was used to test the study hypothesis by using multiple regression analysis to examine the impact of intellectual capital on organizational excellence, intellectual capital on strategic agility, and strategic agility on organizational excellence. To examine the mediating effect of strategic agility in the relationship between intellectual capital and organizational excellence a hierarcal regression analysis was also used.

\section{Factor Analysis and Reliability Coefficients}

In analyzing the data, the exploratory factor analysis was used. Intellectual capital included 12 items, organizational excellence included 18 items, and strategic agility contained 9 items. The summary of the construct of factor analysis is shown in Table 2. In the reliability scale, Cronbach's alpha was used to examine the consistency of the measurement variables (Sekaran \& Bougie, 2013). According to Hsu, Liu, and Lee (2010) who suggested that for items to achieve internal consistency, it should have a value of more than 0.70 with 0.5 being the least acceptable value while Hair, Balck, Babin, Anderson, \& Tatham (2006) suggested that the coefficient should be at the minimum acceptable level 0.74. Controversially, Sekaran and Bougie (2016) indicated that the closer the Cronbach's alpha to the value of 1 , the higher the internal consistency reliability will be. Table 1 shows all the Cronbach's alpha values of the studied variables to be more than 0.70 .

As shown, intellectual capital (IC) dimensions scored Cronbach's alpha value of 0.848 (human capital), 0.917 (structural capital) and 0.857 (relational capital) respectively. Organizational excellence dimensions have a Cronbach's alpha value of 0.762 (structure excellence), 0.873 (cultural excellence), 0.827 (leadership excellence), 0.778 (employee excellence), 0.834 (processes excellence), and 0.892 (technology excellence), while the strategic agility dimensions scored Cronbach's alpha value of 0.834 (strategic sensitivity), 0.907 (leadership unity), and 0.902 (resource fluidity). 
Table 2

Factor Analysis and Reliability Results for Study Variables

\begin{tabular}{llcc}
\hline Variables & Categories & $\begin{array}{l}\text { Factor } \\
\text { loading }\end{array}$ & $\begin{array}{l}\text { Cronbach's } \\
\text { alpha }\end{array}$ \\
\hline Intellectual & Human capital (HC) & 0.947 & 0.848 \\
capital (IC) & Structural capital (SC) & 0.892 & 0.917 \\
& $\begin{array}{l}\text { Relational capital (RC) } \\
\text { Structure excellence }\end{array}$ & 0.889 & 0.857 \\
& (SE) & 0.950 & 0.762 \\
& Culture excellence (CE) & 0.941 & 0.873 \\
& $\begin{array}{l}\text { Leadership excellence } \\
\text { Organizational }\end{array}$ & 0.924 & 0.827 \\
excellence (OE) & $\begin{array}{l}\text { Employee excellence } \\
\text { (EE) }\end{array}$ & 0.891 & 0.778 \\
& $\begin{array}{l}\text { Processes excellence } \\
\text { (PE) }\end{array}$ & 0.872 & 0.834 \\
& Technology excellence & 0.899 & 0.892 \\
& (TE) & 0.901 & 0.834 \\
& $\begin{array}{l}\text { Strategic selectivity } \\
\text { (SS) }\end{array}$ & 0.912 & 0.907 \\
& Leadership unity (LU) & 0.902 \\
\hline Strategic agility & Resource fluidity (RF) & 0.876 & 0.902 \\
\hline
\end{tabular}

\section{Descriptive and Correlation Analysis}

Table 3 shows that the intellectual capital (IC) variable has a mean score of over 3.00; specifically, the three dimensions of IC have mean values of 3.67 (human capital), 3.74 (structural capital), and 3.55 (relational capital). Respondents' attitudes toward the applicability of IC in the Jordan service sector were obviously identified. However, the respondents tended to be more familiar with the organizational excellence atmosphere, in terms of its dimensions, the mean value of 3.92 (structural excellence), 3.75 (cultural excellence), 3.64 (leadership excellence), 3.57 (employee excellence), 3.63 (processes excellence), and 3.59 (technology excellence). Moreover, attitudes toward the strategic agility dimensions have mean values of 3.86 (strategic sensitivity), 3.81 (leadership unity) and 3.85 (resource fluidity). 
The Pearson correlation coefficients computed for the relationships among the study variables were found positive and significant. All the dimensions of intellectual capital were found to be strongly and positively correlated with organizational excellence and strategic agility. Therefore, to summarize, the Pearson correlation matrix indicated that all variables were positively correlated and were significant. The correlation coefficient values were in the range of $0.537(\mathrm{p}<0.01)$ to $0.974(\mathrm{p}<0.01)$.

\section{Hypotheses Analysis}

Tables' 4, 5 and 6 show the results of the regression analysis of hypotheses 1, 2, and 3. Table 4 shows that intellectual capital (IC) explains $71.6 \%$ variances in organization excellence $(\mathrm{OE})\left(\mathrm{R}^{2}=0.716\right.$, $\mathrm{p}<0.01$ ). Additionally, all three dimensions of IC have positive relationships with OE. Human capital (HC) has a standard coefficient beta $(\beta)$ value of 0.873 while structural capital (SC) has a standard coefficient beta $(\beta)$ value of 0.791 . Relational capital (RC) has a standard coefficient beta $(\beta)$ value of 0.839 . All these dimensions had significant p-values which were less than 0.01 . Human capital (HC) dimension had the strongest effect on organizational excellence (OE) as compared to other IC dimensions. Because all three dimensions of IC were found to have a direct and positive effect on $\mathrm{OE}$ at a significant level, H1a, H1b, and H1c are corroborated strongly and hence the first hypothesis (H1) stands confirmed.

Table 5 shows the regression analysis of the second hypothesis. The results depict that intellectual capital (IC) explains $83.4 \%$ variances in strategic agility $(S A)\left(R^{2}=0.834, p<0.01\right)$. All IC dimensions are significantly and positively correlated with the SA: HC $(\beta=0.739, \mathrm{p}$ $<0.01)$, SC $(\beta=0.661, \mathrm{p}<0.01)$, and RC $(\beta=0.643, \mathrm{p}<0.01)$. Human capital (HC) has the strongest effect on $\mathrm{OE}$. The overall results lend strong support to $\mathrm{H} 2 \mathrm{a}, \mathrm{H} 2 \mathrm{~b}$ and $\mathrm{H} 2 \mathrm{c}$ and hence the second hypothesis (H2) stands verified.

Finally, Table 6 demonstrates that $89.7 \%$ variances in organizational excellence (OE) are explained by strategic agility $(\mathrm{SA})\left(\mathrm{R}^{2}=0.897\right.$, $p<0.01)$. As shown in the table, the results indicate that strategic sensitivity (SS) $(\beta=0.659, \mathrm{p}<0.01)$ has a significant influence on OE. Consequently, the third hypothesis (H3) stands validated. 
IJMS 25 (1), 133-153 (2018)

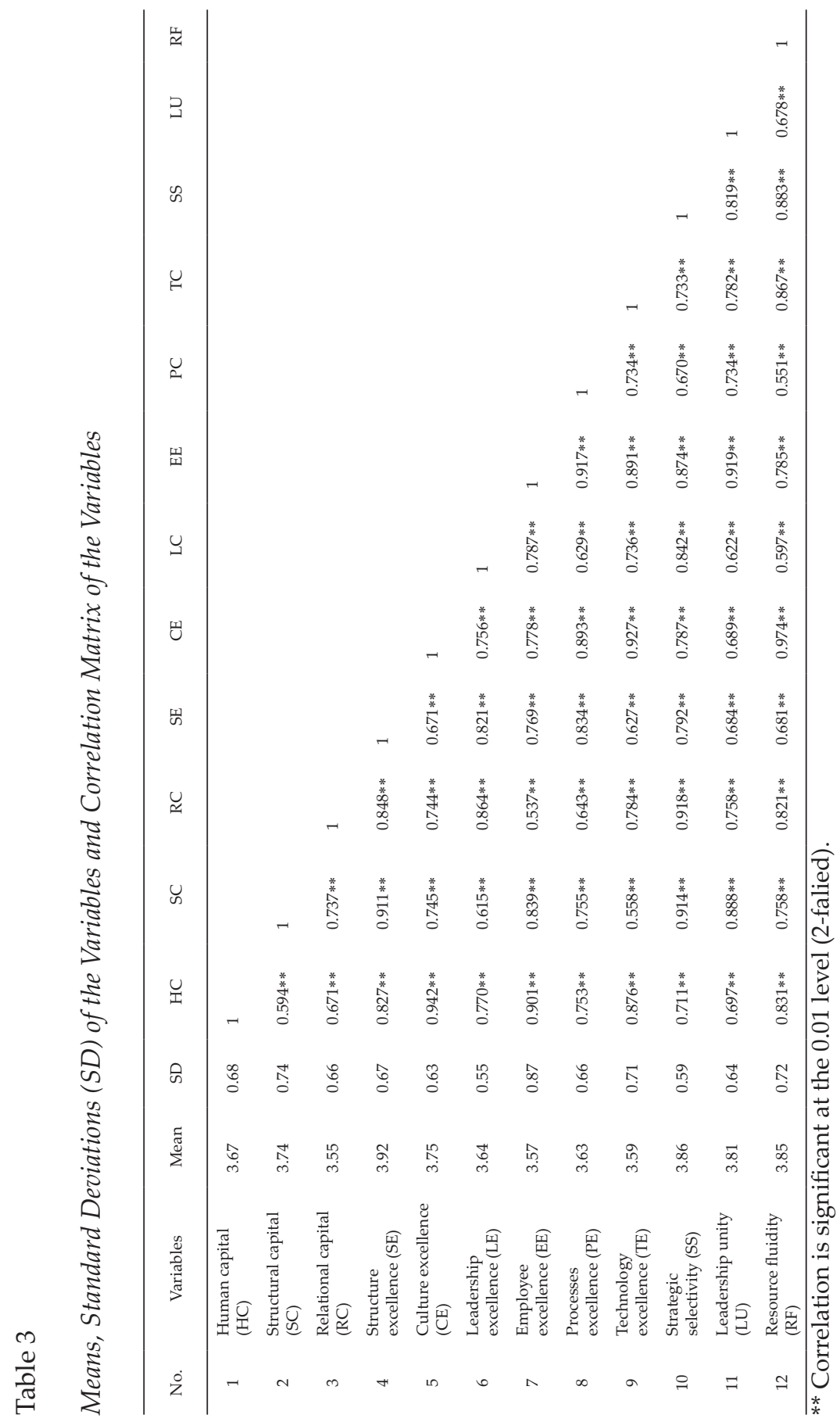


Table 7 presents the results of the test on the mediating effect of strategic agility on the relationship between IC and OE. Baron and Kenny (1986) said that a series of three interconnected conditions must be fulfilled: (a) the independent variable (intellectual capital, IC) must have a significant effect on the mediator (strategic agility, SA), (b) the independent variable (intellectual capital, IC) must have a significant effect on the dependent variable (organizational excellence, $\mathrm{OE}$ ) and (c) the mediator (strategic agility, SA) must have a significant effect on the dependent variable (organizational excellence, $\mathrm{OE}$ ).

Table 4

Regression Analysis of Intellectual Capital on Organizational Excellence

\begin{tabular}{lc}
\hline \multicolumn{1}{c}{ Variable } & Standard coefficient beta $(\beta)$ \\
\hline Intellectual capital Dimensions & \\
Human capital (HC) & $0.873 * *$ \\
Structural capital (SC) & $0.791 * *$ \\
Relational capital (RC) & $0.839 * *$ \\
\hline $\mathrm{R}^{2}$ & 0.716 \\
Adjusted $\mathrm{R}^{2}$ & 0.684 \\
Sig. F & $410.52 * *$ \\
$* *$ Regression is significant at the 0.01 level $(\mathrm{p}<0.01)$.
\end{tabular}

Table 5

Regression Analysis of Intellectual Capital on Strategic Agility

\begin{tabular}{lc}
\hline \multicolumn{1}{c}{ Variable } & Standard coefficient beta $(\beta)$ \\
\hline Intellectual capital Dimensions & \\
Human capital (HC) & $0.739 * *$ \\
Structural capital (SC) & $0.661 * *$ \\
Relational capital (RC) & $0.643 * *$ \\
\hline $\mathrm{R}^{2}$ & 0.834 \\
Adjusted $\mathrm{R}^{2}$ & 0.796 \\
Sig. F & $278.11 * *$ \\
$* *$ Regression is significant at the 0.01 level $(\mathrm{p}<0.01)$. &
\end{tabular}


IJMS 25 (1), 133-153 (2018)

Table 6

Regression Analysis of Strategic Agility on Organizational Excellence

\begin{tabular}{ll}
\hline \multicolumn{1}{c}{ Variable } & Standard coefficient beta $(\beta)$ \\
\hline Strategic agility Dimensions & \\
Strategic sensitivity (SS) & $0.659 * *$ \\
Leadership unity (LU) & $0.637 * *$ \\
Resource fluidity (RF) & $0.702 * *$ \\
\hline $\mathrm{R}^{2}$ & 0.897 \\
Adjusted $\mathrm{R}^{2}$ & 0.832 \\
Sig. F & $199.48 * *$ \\
$* *$ Regression is significant at the 0.01 level $(\mathrm{p}<0.01)$.
\end{tabular}

Tests for mediation were conducted, that is, if there were significant relationships from (1) through (3), a hierarchical regression analysis was performed on all IC dimensions (independent variable) with SA (mediator) and OE (dependent variable) to investigate the type of the mediation as to whether it was full or partial mediation (Yasin, Ramayah, Mohamad, \& Wah, 2009). Moreover, the two cases were to determine if the mediation was full or partial when the effect of the mediator was added to the relationship but the independent variable was no longer significant, then the finding supported full mediation. However, when the independent variable was still significant, but the beta coefficient was decreased, the finding supported partial mediation.

Therefore, Table 7 presents the results of the hierarchical regression in testing the mediating effect of strategic agility on the relationship between intellectual capital and organizational excellence. Based on the results in Table 7, two models of regression were employed; the first model was without a mediator and the second model was with a mediator. There was strong evidences that intellectual capital dimensions have a positive influence on organizational excellence in model 1 , while in model 2 , there was no such positive relationship between intellectual capital dimensions and organizational excellence. As for the mediator (strategic agility), it also did not influence organizational excellence $(\beta=0.472)$ which was not significant at $p<0.01$. Comparing the results between model 1 and model 2 , the findings reveal that the standard beta coefficient of intellectual capital dimensions decreased from 0.459 to 0.422 in the case of human capital, 
from 0.581 to 0.475 in the case of structural capital, and from 0.438 to 0.349 in the case of relational capital. All IC dimensions did not have significant values at $p<0.01$ level. Thus, this shows that the mediator (strategic agility) fully mediates the relationship between intellectual capital and organizational excellence.

\section{Table 7}

Regression Analysis Results for the Mediation of Strategic Agility

\begin{tabular}{|c|c|c|c|}
\hline Variable & $\begin{array}{l}\text { Std. beta } \\
\text { without } \\
\text { mediator } \\
\text { (Model 1) }\end{array}$ & $\begin{array}{l}\text { Std. beta } \\
\text { with } \\
\text { mediator } \\
\text { (model 2) }\end{array}$ & Results \\
\hline $\begin{array}{l}\text { Independent variables: } \\
\text { Intellectual capital }\end{array}$ & & & \\
\hline Human capital (HC) & $0.459^{* *}$ & 0.422 & Full mediation \\
\hline Structural capital (SC) & $0.581^{* *}$ & 0.475 & Full mediation \\
\hline Relational capital (RC) & $0.438^{* *}$ & 0.349 & Full mediation \\
\hline Mediator: Strategic agility & & 0.472 & \\
\hline $\mathrm{R}^{2}$ & 0.427 & 0.566 & \\
\hline Adjusted $\mathrm{R}^{2}$ & 0.421 & 0.559 & \\
\hline $\mathrm{R}^{2}$ Change & 0.427 & 0.139 & \\
\hline F-Change & 99.57 & 112.51 & \\
\hline
\end{tabular}

**Regression is significant at the 0.01 level $(\mathrm{p}<0.01)$.

\section{Discussion}

\section{Relationship between IC and OE}

In the service sector of Jordan, intellectual capital has a significant positive relationship with organizational excellence. Among the three dimensions of IC, human capital (HC) has the strongest effect on OE. In other words, managers in the Jordan service sector consider human capital as the generator of the companies in this sector and as a source of the prerequisites for them to follow the suggestions posted therein. This is followed by relational capital with the second strongest effect 
on OE. Customers are considered the core service sector to be served by companies who in turn give them the competitiveness over other rivals in the same industry. Moreover, a good and strong relationship between an organization and its stakeholders will eventually make it easy to achieve its success as well as this makes it clear that the three IC beliefs are crucial for the success of organizational excellence.

\section{Relationship between IC and SA}

The validation of the second hypothesis is propounded by the current study. The results showed that all three dimensions of the intellectual capital variable, especially human capital, are significantly and positively correlated with strategic agility. This implies that the managers in the Jordan service sector rely on and invest in human capital as strong determinants of their attitudes. The human body is considered the cornerstone of anticipating changes in the environment that affect the organizations' strategic plans and goals. In today's continually evolving global business environment, high-performing human capital has the ability to bring in the sustainable competitive advantage and can quickly seize opportunities through maximizing the organizations' resources. Although many organizations have focused on improving their human capital, its HR departments still lack the agility to support the organizations' directions through managing human capital. However, organizations should integrate its HR strategy (Strategic HR) with its strategy, the more human capital is considered as a strategic asset, the more human capital is committed and loyal to the business strategy. Masnabadi, Chitgar and Azizi (2015) concluded that human capital has positive and significant relationship with strategic agility. Human capital dimensions predict strategic agility as well.

\section{Relationship between SA and OE}

The present study found a positive association between strategic agility and organization excellence of the Jordan service sector which has been confirmed by earlier studies (Nafei, 2016; Alshalabe, Aladwan, Abu Orabi, \& Alwekhyan, 2017; Kuleelung \& Ussahawanitchakit, 2015). As far as the effects of strategic agility on other organizational excellence are concerned, the present findings supports the relationship between strategic agility and organizational excellence dimensions, namely 
structural excellence, cultural excellence, leadership excellence, employee excellence, processes excellence and technology excellence, in the context of service sector mobility. Previous studies concluded that responsiveness, competency, flexibility and speed disclose positive effects on consequences significantly. In addition, marketing effectiveness, organizational productivity, business excellence and competitive advantage increasingly demonstrate significantly positive association with firm performance. Long-term vision, market culture and resource richness are the antecedents of the organizational agility scheme.

\section{Strategic Agility as a Mediator}

The results showed that all three intellectual capital dimensions are significant in model 1 but not significant in model 2 and that strategic agility does not positively influence the organization's excellence in the service sector of Jordan. This, in turn, suggests that strategic agility fully mediates the relationship between intellectual capital and organizational excellence. This means that intellectual capital should possess strategic thinking capabilities and behave strategically which in turn will lead to an increase in individual agility. The collective individuals' agility consorted with organization agility would enhance organizational excellence. The more organizations develop and retain their intellectual capital, the more organizations will be agile and generate the highest success in the turbulent environment.

\section{Conclusion}

In this study, we examined the effect of intellectual capital on organizational excellence in the Jordan service sector while considering strategic agility as a mediator. The overall findings proved that strategic agility fully mediates the relationship between intellectual capital and organizational excellence in the Jordan service sector, and thus this proved that the significant implications for the service sector decision-makers and companies are important. It provides empirical findings that could help managers to gain insights into organizational excellence, particularly in the context of Jordan. Service companies should understand the importance of intellectual capital as a strategic player in enhancing organizational excellence.

Therefore, decisions-makers of the service sector should ensure continuous and consistent services that not only satisfy their 
customers but also either meet or exceed their customers' expectations. Furthermore, this implication applies to companies worldwide as well. Moreover, business organizations, especially service companies, need to create synergies between their intellectual capital that are strategically equipped with agility and local needs (customers' needs) as well as dynamic organizational visions toward achieving the excellence at all levels.

Agile organizations are fenced with intellectuals and talented workers. Yet, to achieve excellent performance as well as organizational excellence needs steps beyond only following the strategic formulation and execution but ensuring sustainability based on continuity, flexibility and comprehensiveness of resources which are becoming the master key of excellence.

\section{Acknowledgment}

This paper was supported by the World Islamic Science and Education University in collaboration with Amman Arab University. We thank our colleagues from both institutions who provided insight and expertise that greatly assisted the research, although they may not agree with all of the interpretations/conclusions of this paper. We thank the president of both universities for their full support and assistance as well as our colleagues for their comments that greatly improved the manuscript

\section{References}

Abu-Radi, S. (2013). Strategic agility and its impact on the operations competitive capabilities in Jordanian Private Hospitals. Master Thesis (Unpublished). Middle East University, Jordan.

Al-Qeed, Marzouq A., Al-Raggad, Mohammad A., Al-Shura, Mohammed S., AlQaisieh, Nasri M., \& Al-Azzam, Zeyad F. (2016). The impact of ideal employee award on the retention of distinctive competencies in public sector organizations in the Hashemite Kingdom of Jordan: A field study of public sector employees who obtained the Ideal Employee Award Civil Service Bureau. International Journal of Business and Social Science, 7(3), 104-114.

Al-Saudi, M. (2008). The impact of TQM implementation on organizational excellence in commercial banks operating in Jordan (in Arabic). Jordan Journal of Business Administration, $4(3), 257-287$. 
Alshalabe, Feras Suleiman, Aladwan, Atef Saleh, Abu Orabi, Tareq Galeb, \& Alwekhyan, F. A.(2017). The impact of agility management style on the organizational excellence (Agility): Field study on Jordanian commercial banks. International Journal of Economics, Commerce and Management, V(1), 284-304.

Arbussa, Anna, Bikfalvi, Andrea, \& Marquès, P. (2017). Strategic agility-driven business model renewal: The case of an SME. Management Decision, 55(2), 271 - 293. doi: http://dx.doi. org/10.1108/MD-05-2016-0355.

Baron, R. M., \& Kenny, D. A. (1986). The moderator-mediator variable distinction in social psychological research: Conceptual, strategic, and statistical considerations. Journal of Personality and Social Psychology, 51(6), 1173-1182.

Bhatti, W., \& Zaheer, A. (2014). The role of intellectual capital in creating and adding value to organizational performance: A conceptual analysis. The Electronic Journal of Knowledge Management, 12(3), 187-194.Available online at www.ejkm.com

Bontis, N. (1999). Intellectual capital: An exploratory study that develops measures and models. Management Decision, 36(2), 63-76.

Bontis, N., Richards, D., \& Serenko, A. (2011). Improving service delivery: Investigating the role of information sharing, job characteristics, and employee satisfaction. The Learning Organization, 18(3), 239 - 250.

Curado, C., Henriques, L., \& Bontis, N. (2011). Intellectual capital disclosure payback. Management Decision, 49(7), 1080-1098.

Dahlgaard, J., \& Dahlgaard, S. (1999). Integrating business excellence innovation management: Developing a culture for innovation, creativity and learning. Total Quality Management, 10(4/5), 465472.

Dehaghi, A. K., \& Navabakhsh, M. (2014). Study the effect of organizational factors to implementing the agility strategy in Isfahan Municipality. International Journal of Academic Research in Business and Social Sciences, 4(1), 315-326.

Doz, Yves L., \& Kosonen, M. (2008). The dynamics of strategic agility: Nokia's rollercoaster experience. California Management Review, 50(3), 95-118.

Doz, Yves L., \& Kosonen, M. (2010). Embedding strategic agility a leadership agenda for accelerating business model renewal. Long Range Planing, 43(2-3), 370-382.

Doz, Yves L., \& Kosonen, M. (2010). Governments for the future: Building the strategic and agile state. Sitra Studies. Retrieved from https://media.sitra.fi/2017/02/23222725/Selvityksia80.pdf. 
Foster, N. (2002). Management excellence through corporate culture: The HP way. The Management Case Study Journal, 1(3), 33-52.

Ghafuri, P., Farhadi, A., \& Mansouri, A. (2014). Relationship between intellectual capital and organizational agility with mediatory role of employee empowering in service sector (Case Study: Karafarin Insurance Company). International Journal of Economy, Management and Social Sciences, 3(12), 11-15.

Hair, Joseph F., Black, William C., Babin, Barry J., Anderson, Roth E., \& Tatham, Ronald L. (2006). Multivariate data analysis ( $6^{\text {th }}$ ed.). Pearson Education International, New Jersey.

Hui, Khoo Hsien, \& Chuan, Tan Kay (2002). Nine approaches to organizational excellence. Journal of Organizational Excellence, 22(1) 53-65.

Hsu, Ya-Hui, \& Fang, Wenchang (2009). Intellectual capital and new product development performance: The mediating role of organizational learning capability. Technological Forecasting $\mathcal{E}$ Social Change, 76(5), 664-677. doi: http://dx.doi.org/10.1016/j. techfore.2008.03.012

Hsu, Chien-Lung, Liu, Chia-Chang, \& Lee, Yuan-Duen. (2010). Effect of commitment and trust towards microblogs on consumer behavioral intention: A relationship marketing perspective. International Journal of Electronic Business Management, 8(4), 292303.

Kazmi, Syeda Asiya Zenab, \& Naaranoja, Marja (2015). Cultivating strategic thinking in organizational leaders by designing supportive work environment!. $3^{\text {rd }}$ International Conference on Leadership, Technology and Innovation Management. Procedia - Social and Behavioral Sciences, 181, 43 - 52.

Kuleelung, Thareerat, \& Ussahawanitchakit, Phaprukbaramee (2015). Organizational agility and firm performance: Evidence from Information and Communication Technology (ICT) Businesses in Thailand. $6^{\text {th }}$ International Trade and Academic Research Conference (ITARC), 9-10 November 2015, UK. The Business and Management Review, 7(1), 206-217.

Irtaimeh, Hani J. (2017). Impact of strategic leadership competencies on enhancing core competencies in organizational "Applied Study on AlManaseer Group". International Journal of Advanced Research (IJAR), 5(2), 2528-2538. doi: http://dx.doi.org/10.21474/ IJAR01/3436\#sthash.yY19J0MB.dpuf

Irtaimeh, Hani J., Al-Azzam, Zeyad F., \& Al-Qaraan, Atif B. (2016). Impact of intellectual capital on Carrefour internal growth 
strategies (Ansoffs Model) in Governorate of Irbid. European Journal of Business and Management, 8(5), 53-66.

Ismail, Hossam S., Poolton, Jenny, \& Sharifi, Hossein (2011). The role of agile strategic capabilities in achieving resilience in manufacturing-based small companies. International Journal of Production Research, 49(11), 5469-5487. doi: http://dx.doi.org/10. 1080/00207543.2011.563833

Ling, Y.H. (2011). The influence of intellectual capital on organizational performance - Knowledge management as moderator. Asia Pacific Journal of Management. doi:10.1007/s10490-011-9257-5

Ling, Y. H. (2012). The influence of intellectual capital on global initiatives. The special issue of the vine journal of information and knowledge management systems: Managing knowledge processes for value creation, 42(1), forthcoming.

Ling, Y. H., \& Jaw, B. S. (2006). The influence of international human capital on global initiatives and financial performance. The International Journal of Human Resource Management, 17(3), 379398.

Masnabadi, Nasrin, Chitgar, Ali, \& Azizi, Mehdi. (2015). The relationship between human capital and strategic agility of faculty members at Islamic Azad Universities, Roudehen Branch. International Journal of Review in Life Sciences, 5(7), 12231227.

Mavengere, Nicholas Blessing. (2014). Role of information systems for strategic agility in supply chain setting: Telecommunication industry study. The Electronic Journal Information Systems Evaluation, 17(1), 100-112. Available online at www.ejise.com

McCann, J., Selsky, J., \& Lee, J. (2009). Building agility, resilience, and performnce in turbulent environment. People \& Strategy, 32(3), 44-51.

McNamara, C. (1997). Organizational excellence. Business \& Economic Review, Jul-Sep, 19-22.

Mohammad, N. A., Ansari, M., Ologbo, A. C., \& Rezaei, G. (2013). Investigating the effect of intellectual capital on organizational performance and mediating role of entrepreneurial orientation. International Review of Business Research Papers, 9(3), 99-113.

Nafei, Wageeh A. (2016). The role of organizational agility in enhancing organizational excellence: A study on telecommunications sector in Egypt. International Journal of Business and Management, 11(4), 121-135.

Qin, R., \& Nembhard, D. A. (2010). Workforce agility for stochastichally diffused conditions- A real option perspective. International Journal of Production and Economics, 125, 324-334. 
Sasmita, P., \& Nayantara, P. (2003). Measuring effectiveness of TQM training: An Indian study. International Journal of Training and Development, 7(3), 203-216.

Sekaran, Uma, \& Bougie, Roger. (2016). Research methods for business: A skill-building approach $\left(7^{\text {th }}\right.$ ed.). Wiley, New York

Sekaran, U., \& Bougie, R. (2013). Research methods for business: A skill-building approach ( $6^{\text {th }}$ ed.). Wiley, New York.

Sharabati, Abdul-Aziz A., Jawad, Shawqi N., \& Bontis Nick (2010). Intellectual capital and business performance in the pharmaceutical sector of Jordan. Management Decision, 48(1), 105-131.

Stewart, T. (1997). Intellectual capital: The new wealth of organizations. New York: Doubleday/Currency.

Subramanian, M., \& Youndt, M. A. (2005). The influence of intellectual capital on the types of innovative capabilities. Academy of Management Journal, 48(3), 450-463.

Tallon, P. P., \& Pinsonneault, A. (2011). Competing perspectives on the link between strategic information technology alignment and organizational agility: Insights from a mediation model. MIS Quarterly, 35(2), 463-486.

Wu, S. H., Lin, L. Y., \& Hsu, M. Y. (2007). Intellectual capital, dynamic capabilities and innovative performance of organizations. International Journal of Technology Management, 39(3/4), 279-296.

Yasin, Norjaya Mohd, Ramayah, T., \& Mohamad, Osman. (2009). The mediating effects of attitude towards parallel imports in consumer personality - Purchase intention linkage. Jurnal Pengurusan, 28, 103-123.

Youndt, M. A., Subramaniam, M., \& Snell, S. A. (2004). Intellectual capital profiles: An examination of investments and returns. Journal of Management Studies, 41, 335-362. 